\title{
Perbandingan Algoritma Multi-Thresholding, Konversi Biner, Low-Pass Filtering pada Segmentasi Rambut Kaki
}

\author{
${ }^{1}$ Ridan Nurfalah, ${ }^{2}$ Sri Hadianti*, ${ }^{3}$ Nissa Almira Mayangky, ${ }^{4}$ Muhammad Faitullah Akbar \\ ${ }^{1,2,3}$ Sistem Informasi, STMIK Nusa Mandiri, \\ Jl. Raya Jatiwaringin no 2, Cipinang Melayu, Makassar, Jakarta Timur \\ ${ }^{4}$ Sistem informasi, Fakultas Teknik \& Informatika, Universitas Bina Sarana Informatika \\ Jl. Kramat Raya no 98, Kwitang, Senen, Jakarta Pusat \\ *e-mail: sri.shv@nusamandiri.ac.id
}

(received: 10 November 2020, revised: 25 Desember 2020, accepted: 1 Januari 2021)

\begin{abstract}
Abstrak
Rambut berada tersebar pada bagian tubuh manusia dan memiliki fungsi yang berbeda, untuk mementingkan estetika tidak sedikit orang yang melakukan pencukuran rambut pada beberapa bagian tubuh, salah satunya bagian kaki. Terdapat banyak metode pencukuran yang tersedia saat ini, mulai dari cara alami, terapi, modern sampai penggunaan laser, namun pada penelitian ini berfokus pada metode laser. Pencukuran rambut dengan metode laser kelebihannya dapat menghilangkan rambut dalam jangka waktu yang cukup lama dengan pengaplikasian yang cukup mudah, dan tidak memerlukan waktu yang lama dibandingkan dengan teknik pengaplikasian tradisional. Dengan permasalahan itu dibutuhkan sistem yang bisa membedakan wilayah rambut dan kulit, sehingga tujuan untuk hair removal lebih fokus pada bagian rambut dan tidak mencederai bagian atau lapisan kulit. Pemisahan dua bagian tersebut dilakukan dengan cara segmentasi helai rambut dan menghilangkan bagian kulit. Empat metode dibandingkan dalam penelitian ini yaitu multi-thresholding, Konversi biner, low-filter dan highfilter, hasil dari perbandingan empat metode diketahui jika metode Multi-Thresholding diyakini dapat melakukan segmentasi rambut dengan baik, karena pola rambut dapat terlihat jelas dan tidak banyak noise yang terlihat.
\end{abstract}

Kata Kunci: konversi biner, low-pass filtering, multi-thresholding, high-pass filtering, segmentasi

\begin{abstract}
Hair is scattered in various parts of the human body and has different functions. To emphasize the aesthetics, many people shave their hair on several parts of the body, one of which is the legs. Today, there are many shaving methods, ranging from natural, therapeutic, modern to laser use, but this research focuses on laser methods. Laser hair removal has the advantage that it can remove hair in a fairly long period of time with a fairly easy application and does not require a long time compared to traditional application techniques. With this problem, a system that can differentiate between hair and skin areas is needed so that hair removal aims to focus more on the hair and not injure any part or layer of the skin. The separation of the two parts is done by segmenting the hair strands and removing part of the skin. Four methods were compared in this study, namely multi-thresholding, binary conversion, low-filter, and high-filter. Comparing the four methods shows that the multi-thresholding method is believed to segment hair well because the hair pattern can be seen clearly, and not much noise is visible.
\end{abstract}

Keywords: binary conversion, low-pass filtering, multi-thresholdinghigh-pass filtering, segmentation

\section{Pendahuluan}

Setiap manusia memiliki rambut yang menyebar hampir di seluruh bagian tubuh. Rambut yang ada pada tubuh manusia memiliki fungsi tersendiri di setiap bagiannya, bukan hanya tentang estetika tetapi perlindungan untuk bagian tubuh itu sendiri [1]. Rambut terdiri dari dua bagian utama, yaitu bagian akar dan batang atau tangkai. Pentingnya keberadaan rambut dalam tubuh yaitu untuk perlindungan atau kehangatan dan keindahan, sebagai penunjang penampilan, pemotongan rambut 
pada beberapa bagian tubuh menjadi hal yang dipertimbangkan untuk beberapa orang [1]. Pertimbangan yang sudah biasa pada kalangan masyarakat adalah menghilangkannya rambut pada bagian kaki dengan cara hair removal [2].

Terdapat banyak cara hair removal yang ada hingga saat ini, mulai dari cara alami, terapi, hingga laser yang bersifat sementara ataupun dalam jangka yang cukup lama untuk penumbuhan kembali. Salah satu teknik hair removal yang penggunaannya cukup meningkat adalah laser hair removal [3].

Laser hair removal menjadi opsi yang banyak dipilih karena kelebihannya bisa menghilangkan rambut dalam jangka waktu yang cukup lama dengan pengaplikasian yang cukup mudah, dan tidak memerlukan waktu yang lama dibandingkan dengan teknik pengaplikasian cara terapi atau tradisional [4]. Saat ini target dari teknik laser hair removal terfokus pada bagian kulit dengan cara mengukur bagian pori dengan alat dan memindai pada seluruh area tanpa ada panduan khusus [5]. Pigmen penyerap cahaya (chromophores) yaitu bagian melanin menjadi wilayah target terpindai yang berada di dalam folikel rambut menyerap radiasi laser dan konversi radiasi menjadi panas. Karena penyerapan laser, kerusakan fototermal terjadi pada folikel rambut dan batang rambut berdasarkan "Teori Fototermolisis Selektif" yang mengakibatkan pengangkatan rambut secara permanen [6]. Meskipun ada peringatan yang diambil dalam sistem ini untuk menghindari memanaskan struktur kulit yang mengandung melanin dan kromofor kulit lainnya, risiko cedera epidermis yang tidak diinginkan seperti hiperpigmentasi, lepuh, keropeng, bekas luka, dan tromboflebitis dapat terjadi setelah operasi pengangkatan rambut [7].

Melihat permasalahan tersebut dibutuhkan sistem yang bisa membedakan wilayah rambut dan kulit, sehingga tujuan untuk hair removal lebih fokus pada bagian rambut dan tidak mencederai bagian atau lapisan kulit. Penelitian ini berfokus pada pemisahan dua bagian tersebut, yaitu bagian helai rambut dan kulit pada wilayah kaki. Pemisahan dua bagian tersebut dilakukan dengan cara segmentasi helai rambut dan menghilangkan bagian kulit. Empat metode dilakukan pengujian yaitu Multi-Thresholding, Konversi Biner, low-filter dan high-filter.

Sebelumnya ada beberapa penelitian yang telah dilakukan deteksi rambut, beberapa diantaranya adalah yang dilakukan oleh [8] dimana penelitian tentang deteksi rambut menggunakan metode machine learning, pada penelitian tersebut dapat disimpulkan jika metode yang digunakan dapat melakukan pemisahan antara rambut dengan kulit. Selain penelitian [8], ada juga penelitian tentang kondisi akar rambut di kepala dengan tanpa harus memotongnya terlebih dahulu, pada penelitian yang dilakukan [9] dapat diketahui jika kondisi dari akar rambut kepala dapat dideteksi kondisinya tanpa harus dilakukan pemotongan pada rambut kepala, adapun penelitian tentang rambut yaitu dilakukan oleh [10] dimana penelitian tersebut berawal dari tindakan medis yang memerlukan perhitungan rambut secara manual sehingga untuk memudahkan itu dibuat rancangan sistem untuk perhitungan rambut secara otomatis dengan dimulai dengan proses segmentasi rambut.

Dari beberapa penelitian diatas dapat diketahui jika belum ada penelitian yang meneliti rambut yang berada pada bagian kaki untuk tujuan mempermudah proses laser hair removal, sehingga dibuatlah penelitian awal mengenai hal tersebut dengan melakukan segmentasi rambut kaki.

\section{Tinjauan Literatur}

Pada penelitian ini dilakukan pengambilan pustaka dari berbagai referensi untuk menunjang hasil penelitian yang lebih maksimal dan sesuai dengan tujuan penelitian. Berikut tinjauan pustaka pada penelitian ini:

\section{A. Citra Digital}

Pemrosesan citra dapat digunakan untuk mengekstraksi hasil optik yang memiliki detail dan makna dari suatu citra [11]. Citra digital dikatakan sebagai larik (array) adata yang memiliki nilai-nilai real atau nilai-nilai kompleks. Nilai-nilai tersebut ditampilkan dalam bentuk deretan bit yang sesuai dengan fungsi nilai itu sendiri. $F(a, b)$ didefinisikan sebagai fungsi citra digital, yang mempunyai jumlah $X$ sebagai baris dan Y sebagai kolom, dimana a dan b disebut sebagai koordinat spasial, sedangkan amplitudo $f$ pada titik koordinat $(\mathrm{a}, \mathrm{b})$ merupakan tingkat keabuan yang diambil dari citra diambil pada titik tersebut. Jika nilai a, b, dan amplitudo f seluruhnya berhingga (finite) dan memiliki nilai diskrit 
maka citra tersebut merupakan citra digital [12]. Contoh dari koordinat citra dapat dilihat pada Gambar 1 di bawah ini:

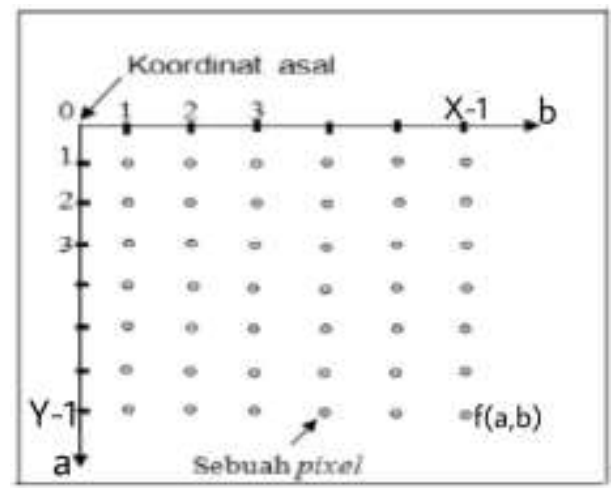

Gambar 1. Koordinat Citra Digital

B. Segmentasi Citra

Segmentasi citra merupakan pemisahan suatu objek dengan objek yang lain atau pemisahan suatu objek dengan latar belakang yang ada pada sebuah citra. Dengan dilakukannya segmentasi maka suatu objek dipisahkan secara individu dengan objek yang lainnya. Tujuan dari segmentasi ini adalah untuk mempermudah area yang akan dilakukan analisis (area of interest) sehingga tidak membingungkan pada saat analisis dan menimbulkan multi persepsi [12].

Segmentasi citra memiliki beberapa teknik untuk membagi Gambar menjadi beberapa segmen. Setiap teknik memiliki ciri khasnya sendiri. Semua teknik ini mengikuti dua pendekatan dasar untuk segmentasi gambar. Kedua pendekatan tersebut adalah pendekatan region-based dan pendekatan edgebased. Semua teknik segmentasi citra secara garis besar dibagi menjadi tiga bagian[13]. Berikut pada Gambar 2 adalah jenis-jenis teknik dalam segmentasi citra:

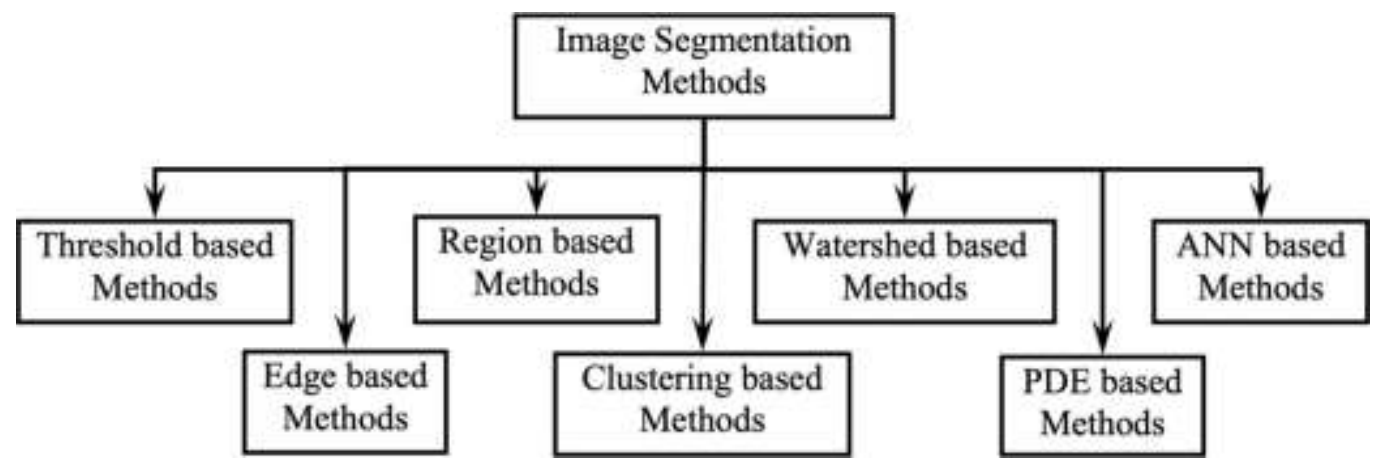

Gambar 2. Jenis-jenis Teknik Segmentasi Citra

Berdasarkan Gambar 2 di atas terdapat 7 teknik dalam melakukan segmentasi dalam pemrosesan suatu citra. Jenis-jenis teknik segmentasi tersebut diantaranya adalah threshold based methods yang digunakan pada penelitian ini untuk melakukan segmentasi pada citra rambut. Selanjutnya adalah edge based methods yang mendeteksi garis besar suatu objek dan batas antara objek dan latar belakang pada citra, selain itu filter deteksi tepi juga dapat digunakan untuk menyempurnakan tampilan pada gambar yang buram [14]. Teknik ketiga adalah regio based methods yang melakukan segmentasi dengan memberikan batasan wilayah tertutup dan kuat terhadap noise acak karena basis statistik yang dimilikinya[15]. Clustering based methods mensegmentasi citra unsupervised dengan mengklasifikasikan gambar ke dalam sejumlah cluster terbatas, di mana jumlah cluster dapat ditentukan oleh pengguna atau algoritma[16]. Watershed based methods yang mensegmentasi citra dengan konsep topological interpretation [13]. PDE based methods menghasilkan tepi dan batas citra menjadi kabur dengan operasi tertutup [13]. Dan ANN based methods yang mensegmentasi dengan konsep neuron otak manusia dan menstimulasikan ke dalam pemrosesan citra [13]. 


\section{Multi-thresholding}

Thresholding adalah salah satu teknik segmentasi yang paling banyak digunakan dalam pemrosesan citra, yang dianggap sebagai masalah klasifikasi piksel. Pada dasarnya ada tiga jenis model thresholding: bi-level, multi-level dan local-thresholding [17].

Untuk citra grayscale, proses bi-thresholding memisahkan citra menjadi dua kelas yaitu foreground dan background. Sedangkan multi-thresholding berguna untuk mensegmentasi citra kompleks menjadi lebih dari dua region / kelas yang homogen. Penemuan nilai threshold yang optimal merupakan proses utama pada bidang bi-level dan multi-thresholding. Namun, kelemahan

utama dari teknik thresholding-based adalah waktu komputasi yang lama ketika jumlah nilai ambang meningkat dan menjadi masalah komputasi yang sulit. Di sisi lain, metode localthresholding mengalokasikan nilai ambang batas yang berbeda untuk setiap wilayah citra. Nilai ambang secara signifikan bergantung pada informasi lingkungan dari piksel yang bersangkutan.

Selain itu, local-thresholding cukup memakan waktu mengingat eksekusi pemrosesan lokalnya

[18]. Multi-thresholding adalah salah satu teknik segmentasi citra, yang secara luas dianggap membagi gambar menjadi beberapa region atau objek untuk menemukan dan menafsirkan informasi

yang berarti pada citra. Dalam proses multi-thresholding, nilai ambang $(T)$ dipilih menggunakan skema pemrosesan sinyal favorit, yang memisahkan gambar ke dalam berbagai cluster. Untuk gambar RGB, menemukan threshold ( $T$ ) terbaik, yang memisahkan gambar menjadi foreground dan background, tetap merupakan langkah yang sangat signifikan dalam segmentasi gambar [15].

Pada penelitian ini multi-threshold digunakan untuk mencari nilai optimal dari $t^{\#}$, yang memaksimalkan fungsi $\left(J_{\max }\right)$ dari setiap komponen variabel $C=\{\mathrm{R}, \mathrm{G}, \mathrm{B}\}$ yang didefinisikan pada persamaan (1) di bawah:

$$
\varphi^{C}=1<t_{j}^{C}<, \ldots, L-1 \max \quad \sigma_{B}^{C^{2}}\left(t_{j}^{C}\right)
$$

Berdasarkan kompleksitas seperti pada fungsi 1 di atas, menyelesaikan segmentasi pada RGB dapat memerlukan komputasi yang tinggi dibanding citra skala abu-abu[19].

\section{Low Pass Filter}

LPF (Low Pass Filter) atau disebut juga smoothing filter akan digunakan dalam penelitian ini sebagai salah satu metode untuk menghilangkan noise acak, noise berkala, dan menampilkan pola latar belakang. Fungsi dasar dari low-pass filter yang ideal adalah untuk memperkirakan rata-rata sebuah piksel dan semua piksel tetangga dan akhirnya mengganti nilai asli dari piksel tersebut. Proses ini berlangsung terus menerus untuk setiap piksel pada citra rambut. Biasanya, low-pass filter melemahkan frekuensi tinggi dan mempertahankan serta tidak merubah frekuensi [20]. Berikut pada persamaan (2) adalah rumus dalam menentukan LPF pada citra:

$$
\operatorname{LPF}(a, b)=\left\{1 \text { if } \sqrt{a^{2}+b^{2}<c f} 0 \text { if } \sqrt{a^{2}+b^{2}>c f}\right.
$$

Dimana $(\mathrm{a}, \mathrm{b})$ merupakan ukuran dari citra dan cf adalah ukuran cut-off yang digunakan untuk segmentasi dengan metode low-pass filter. Dengan menggunakan persamaan 2 di atas dapat menemukan normalisasi background smoothing.

Sedangkan HPF (High Pass Filter) merupakan suatu proses pada gambar/citra dari bentuk filter yang mengambil komponen frekuensi tinggi dan menurunkan komponen frekuensi rendah, karena mengharuskan koefisien matriks sama dengan nol, dalam luapan nilai respons yang dapat ditemui dalam arah negatif maupun positif pada matriks citra [21]. High-pass filter juga digunakan untuk melakukan penajaman citra menjadi grayscale. Penajaman digunakan untuk mendapatkan detail halus dari citra yang disorot. Selain itu, high-pass filter juga digunakan untuk deteksi tepi. Filter ini mempertajam citra dengan membuat overlay kontras tinggi yang menekankan tepi pada citra, sehingga menentukan bahwa citra yang disempurnakan adalah hasil dari penambahan citra asli dan versi skala dari struktur garis dan tepi pada citra. High-pass-filter juga digunakan untuk mempertahankan informasi frekuensi di dalam citra [22]. 


\section{Metode Penelitian}

Dalam penelitian ini melalui beberapa tahap yang harus dilewati, tahapan pada penelitian ini digambarkan pada Gambar 3, dimana dapat dilihat jika penelitian yang dilakukan memiliki beberapa tahapan, yaitu:

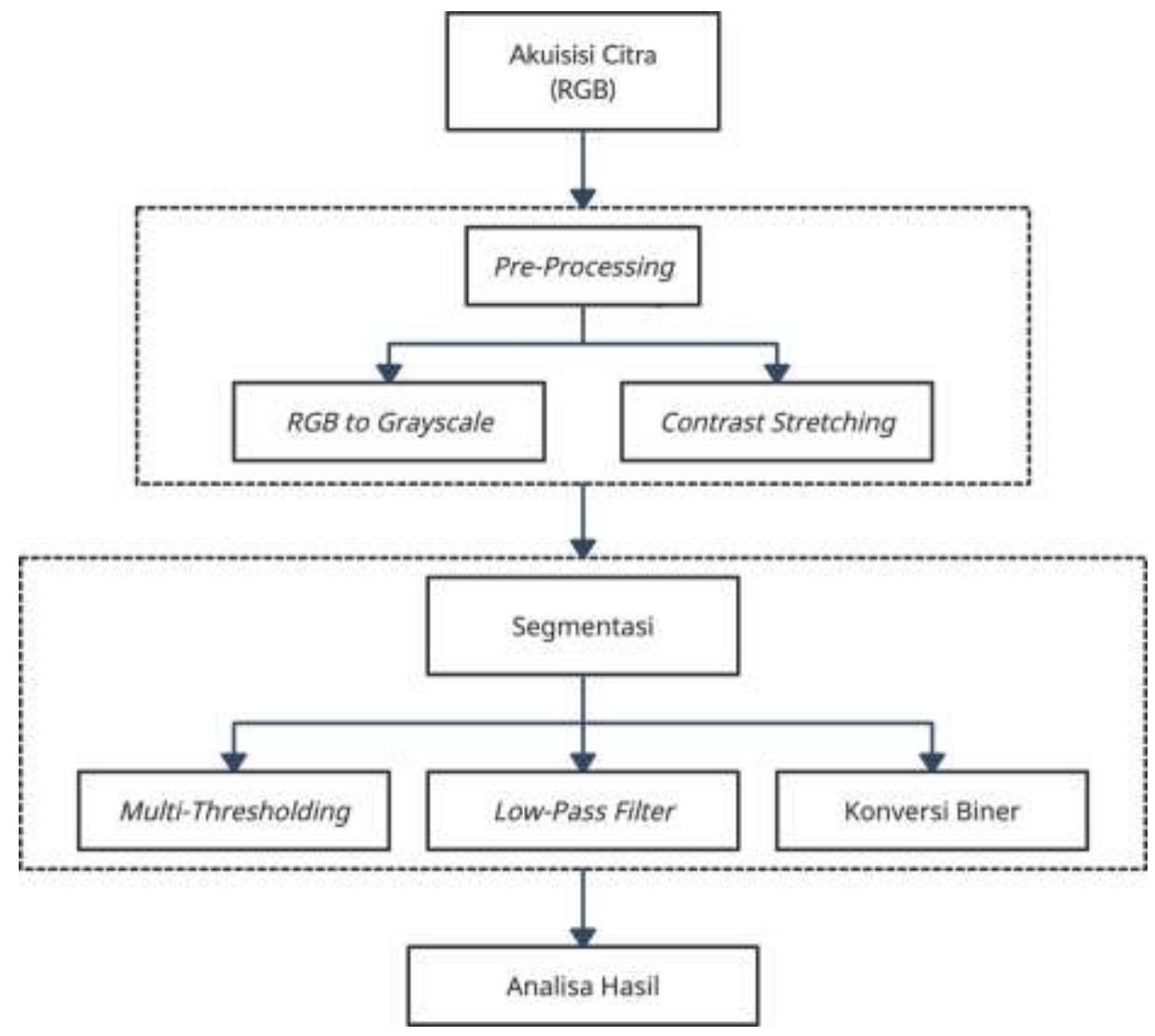

A. Akuisisi Citra

\section{Gambar 3. Metode Penelitian}

Dalam tahapan ini dilakukan pemotretan pada rambut kaki, dengan ketentuan-ketentuan yang disesuaikan yang meliputi ukuran jarak, pencahayaan yang dilakukan saat akuisisi dan kontras yang sama, sehingga hasil piksel yang dikeluarkan dari citra yang telah diakuisisi dapat bernilai sama.

B. Pre-Processing

Dalam tahapan ini dilakukan pre-processing citra dimana citra dilakukan pengubahan pada struktur warnanya, dari warna RGB menjadi grayscale untuk memudahkan dalam proses segmentasi.

C. Segmentasi

Dalam tahapan ini dilakukan segmentasi dengan membandingkan empat metode, yaitu metode multi-thresholding, konversi biner, dan Low-Pass filtering dimana dari keempat metode tersebut dipilih salah satu metode yang paling tepat untuk mendeteksi dataset rambut kaki yang telah disiapkan.

D. Analisis Hasil

Pada tahapan terakhir yaitu menampilkan dari hasil segmentasi yang dilakukan sebelumnya, sehingga dapat dilihat metode segmentasi mana yang lebih baik dari keempat metode yang digunakan. 


\section{Hasil Dan Pembahasan}

Hasil dari penelitian dan pengolahan pada citra yang telah dilakukan pada penelitian ini adalah sebagai berikut:

\section{A. Akuisisi Citra}

Berbeda dengan penelitian sebelumnya, pada penelitian ini akuisisi citra yang dilakukan adalah pengambilan citra rambut kaki yang diambil dari 5 partisipan menggunakan kamera Canon EOS M100 24 megapiksel dengan 18x optical zoom. Jarak pengambil antara kamera dan objek adalah $10 \mathrm{~cm}$ pada pencahayaan natural ruangan, hasil dari akuisisi citra dapat dilihat pada Gambar 4.

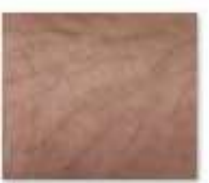

1

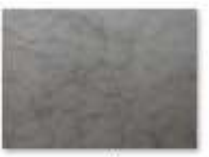

4

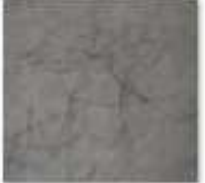

2

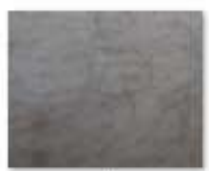

5

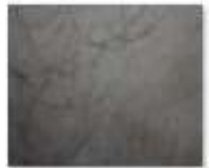

3

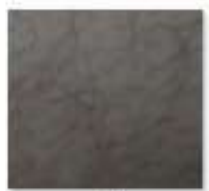

6

Gambar 4. Dataset Citra

B. Pre-Processing

Pada penelitian ini tahap pertama yang dilakukan setelah input image adalah tahap pre-processing dengan menggunakan dua tahapan, yaitu:

1. Mengubah Citra Asli Menjadi Citra Abu-abu (Greyscale)

Mengubah citra asli menjadi grayscale ini bertujuan untuk mengurangi kadar warna red, green, dan blue (RGB) pada citra agar lebih mudah dilakukan pendeteksian objek yang akan dianalisis. Gambar 5 adalah hasil pre-processing dengan grayscale image.
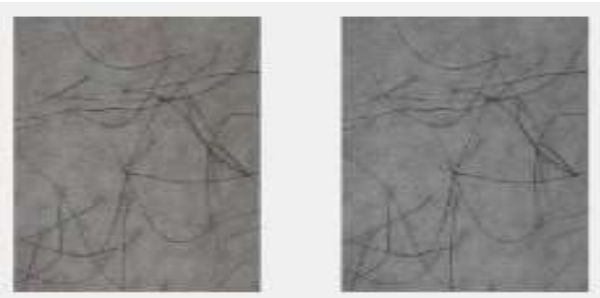

\section{Gambar 5. Citra Asli (Kiri), Citra Grayscale (Kanan)}

2. Menambah Contrast (Contrast Stretching)

Setelah dilakukan pengolahan citra asli menjadi grayscale, tahap selanjutnya adalah melakukan penambahan kontras pada citra untuk menonjolkan warna dan pola rambut itu sendiri dengan tujuan mempermudah saat dilakukan segmentasi citra di tahap selanjutnya. Gambar 6 merupakan gambar dari hasil contrast stretching.
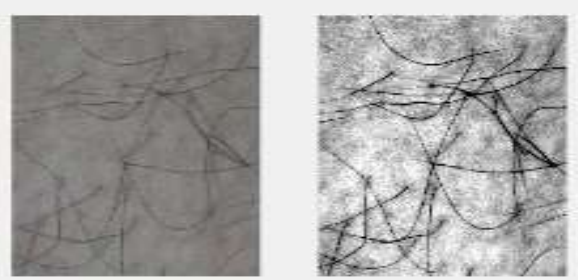

Gambar 6. Citra Asli (Kiri), Citra Contrast Stretching (Kanan) 


\section{Segmentasi}

Tahap segmentasi dilakukan dengan 4 metode yang menunjukkan perbedaan masing-masing metode diantara keempatnya. Tabel 1 merupakan hasil dari 4 metode tersebut :

Tabel 1. Hasil Segmentasi

\begin{tabular}{|c|c|c|c|c|}
\hline No & Citra Asli & $\begin{array}{c}\text { Konversi } \\
\text { Binner }\end{array}$ & $\begin{array}{c}\text { Low Pass } \\
\text { Filtering }\end{array}$ & $\begin{array}{c}\text { Multi- } \\
\text { Thresholding }\end{array}$ \\
\hline 1 & & & & \\
\hline 2 & & & & \\
\hline 3 & & & & \\
\hline 4 & & & & \\
\hline 5 & & & & \\
\hline 6 & & & & \\
\hline 7 & & & & \\
\hline
\end{tabular}

Dari Tabel 1 dapat dilihat hasil beberapa metode se mgmentasi yang dilakukan pada 7 citra rambut kaki manusia. 3 metode melakukan segmentasi citra dengan baik berdasarkan fungsi masing-masing yaitu metode konversi biner berhasil mensegmentasi dengan baik pada 4 dari 7 citra, low-pass filtering berhasil hanya pada 1 dari 7 citra, dan multi-thresholding berhasil mensegmentasi 5 dari 7 citra. 


\section{Analisis hasil}

Berdasarkan hasil segmentasi pada Tabel 1, dapat dilihat pada citra pertama, dilakukan segmentasi dengan sempurna menggunakan metode konversi biner, dapat terlihat jika yang tersegmentasi hanya rambut saja, dan untuk kulit kakinya tidak terdeteksi. Hal tersebut berbeda ketika menggunakan metode Low Pass Filtering, menggunakan metode tersebut masih mendeteksi dari kulit kaki, begitupun ketika menggunakan metode multi-thresholding. Menggunakan metode multi-thresholding baik rambut maupun kulit tidak terdeteksi sama sekali.

Pada citra kedua dapat dilihat jika menggunakan metode konversi biner hanya bagian rambut yang terdeteksi, untuk bagian kulit tidak terdeteksi, namun jika menggunakan metode low pass filtering bagian kulitnya masih terdeteksi sehingga segmentasi tidak sempurna, saat menggunakan metode multithresholding segmentasi dikatakan berhasil dikarenakan yang tersegmentasi hanya rambut saja.

Pada citra ketiga pun sama seperti citra kedua dimana dapat dilihat jika menggunakan metode konversi biner hanya bagian rambut yang terdeteksi, untuk bagian kulit tidak terdeteksi, namun jika menggunakan metode low pass filtering bagian kulitnya masih terdeteksi sehingga segmentasi tidak sempurna, saat menggunakan metode multi-thresholding segmentasi dikatakan berhasil dikarenakan yang tersegmentasi hanya rambut saja.

Pada citra keempat pun tidak jauh beda dengan citra kedua dan ketiga dimana dapat dilihat jika menggunakan metode konversi biner hanya bagian rambut yang terdeteksi, untuk bagian kulit tidak terdeteksi, namun jika menggunakan metode low pass filtering bagian kulitnya masih terdeteksi sehingga segmentasi tidak sempurna, saat menggunakan metode multi-thresholding segmentasi dikatakan berhasil dikarenakan yang tersegmentasi hanya rambut saja.

Pada citra kelima dapat dilihat jika ketiga metode tidak dapat digunakan, hal tersebut juga sama pada citra keenam, dimana ketiga metode yang digunakan tidak berhasil dalam melakukan segmentasi rambut.

Pada citra ketujuh dapat dilihat jika metode konversi biner dan low pass filtering tidak dapat melakukan segmentasi dengan baik, namun metode multi-thresholding dapat mensegmentasi rambut dengan baik tanpa tersegmentasi bagian kulit.

Dari pemaparan diatas dapat diketahui jika dari ketiga metode yang digunakan metode multithresholding lebih cocok digunakan untuk melakukan segmentasi rambut kaki, hal tersebut disebabkan karena citra-citra yang di segmentasi dapat tersegmentasi dengan baik meskipun ada 3 citra yang kurang sempurna.

\section{Kesimpulan}

Dalam penelitian ini, menggunakan beberapa metode segmentasi untuk mendeteksi rambut pada kaki. Metode yang digunakan adalah konversi biner, low-pass filtering, dan multi-thresholding, dari ketiga metode tersebut dapat terlihat jika metode yang paling cocok digunakan pada dataset yang diujikan adalah metode multi-thresholding. Hal tersebut dikarenakan dengan menggunakan metode multi-thresholding dapat mendeteksi hanya bagian rambut saja dengan menghilangkan bagian kulit dari kaki. Untuk menyempurnakan segmentasi dari rambut kaki ini perlu adanya dilakukan penelitian lebih lanjut terutama penambahan metode untuk penambahan kontras, dan penghilang noise, sehingga segmentasi rambut kaki lebih maksimal.

\section{Referensi}

[1] D. K. Sari, A. Wibowo, F. Kedokteran, and U. Lampung, "Perawatan Herbal pada Rambut Rontok Herbal Treatment for Hair Loss," Vol. 5, pp. 129-134, 2016.

[2] L. K. Craig and P. B. Gray, "Pubic Hair Removal Practices in Cross-Cultural Perspective," Cross-Cultural Res., Vol. 53, No. 2, pp. 215-237, 2019.

[3] E. Russe, M. Purschke, M. Herold, F. H. Sakamoto, G. Wechselberger, and K. RusseWilflingseder, "Evaluation of Safety and Efficacy of Laser Hair Removal With the Long-Pulsed 755 Nm Wavelength Laser: A Two-Center Study With 948 Patients," Lasers Surg. Med., Vol. 52, No. 1, pp. 77-83, 2020.

[4] S. Saputri and P. Minerva, "Perbandingan Hasil Pencabutan Bulu pada Kaki (Waxing) Menggunakan Kosmetik Tradisional dan Kosmetik Modern," Vol. 2, No. September, 2019 
[5] A. Alajlan, "Crescent-Shaped Hyperpigmentation Following Laser Hair Removal: Case Series of Fifteen Patients," Lasers Surg. Med., pp. 1-4, 2020.

[6] B. Kawilarang, "Diagnosis dan Tatalaksana Sindrom Treacher Collins," Vol. 17, No. 2, pp. 914, 2019.

[7] M. Avşar and I. S. Yetik, "Hair Region Localization with Optical Imaging for Guided Laser Hair Removal," Senior Member IEEE Department of Electrical and Electronics Engineering Tobb University of Economics and Technology , Ankara 06560, Turkey, pp. 1411-1414, 2015.

[8] R. Kikkawa, H. Sekiguchi, I. Tsuge, S. Saito, and R. Bise, "Semi-Supervised Learning with Structured Knowledge for Body Hair Detection in Photoacoustic Image," Proc. - Int. Symp. Biomed. Imaging (ISBI), April 2019, pp. 1411-1415, 2019.

[9] D. Van Neste, "Viable Terminal Scalp Hair Follicles Constitute A Necessary and Sufficient Biological End-Organ That Conditions Clinical Efficacy of Finasteride In Males with Male Pattern Hair Loss Without Implying Reversal of Miniaturized Follicles," Ski. Res. Technol., Vol. 25, No. 5, pp. 701-711, 2019.

[10] M. Attia, M. Hossny, H. Zhou, S. Nahavandi, H. Asadi, and A. Yazdabadi, "Digital Hair Segmentation Using Hybrid Convolutional and Recurrent Neural Networks Architecture," Comput. Methods Programs Biomed., Vol. 177, pp. 17-30, 2019.

[11] I. Sajedian, J. Kim, and J. Rho, "Finding The Optical Properties Of Plasmonic Structures By Image Processing Using A Combination Of Convolutional Neural Networks and Recurrent Neural Networks," Microsystems Nanoeng., 2019.

[12] N. Nafi, "Algoritma Kohonen Dalam Mengubah Citra Gray Level Menjadi Citra Biner," Vol. 9, No. 2, pp. 49-55, 2015.

[13] E. Anjna, "Review of Image Segmentation Technique," Vol. 8, No. 4, pp. 36-40, 2017.

[14] G. M. Amer and A. M. Abushaala, "Edge Detection Methods," IEEE, 2015.

[15] V. Rajinikanth and N. S. M. Raja, "Robust Color Image Multi-Thresholding Using BetweenClass Variance and Cuckoo Search Algorithm Cuckoo Search," pp. 379-386.

[16] N. Dhanachandra and Y. J. Chanu, "A Survey On Image Segmentation Methods Using Clustering Techniques," Vol. 2, No. 1, pp. 15-20, 2017.

[17] M. Abd, E. Aziz, A. A. Ewees, and A. E. Hassanien, "Hybrid Swarms Optimization Based Image Segmentation," Springer Int. Publ. Ag, 2016.

[18] K. Gopal, D. Arunita, D. Swarnajit, R. Jorge, and G. Sanjoy, Nature - Inspired Optimization Algorithms and Their Application In Multi - Thresholding Image Segmentation, No. 0123456789. Springer Netherlands, 2019.

[19] V. Rajinikanth and M. S. Couceiro, "Rgb Histogram Based Color Image Segmentation Using Firefly Algorithm," Procedia Comput. Sci., Vol. 46, pp. 1449-1457, 2015.

[20] W. Azani, M.- Ieee, H. Yazid, and S. Bin Yaacob, "Illumination Correction of Retinal Images using Superimpose Low Pass and Gaussian Filtering," March, pp. 30-31, 2015.

[21] W. Lin and J. Wang, "Biomedical Signal Processing and Control Edge Detection In Medical Images With Quasi High-Pass Filter Based on Local Statistics," Biomed. Signal Process. Control, Vol. 39, pp. 294-302, 2018.

[22] S. J. Prajapati and K. R. Jadhav, "Brain Tumor Detection By Various Image Segmentation Techniques With Introduction to Non Negative Matrix Factorization," Vol. 4, No. XX, pp. 1$6,2015$. 